\title{
Waar is God? Relevante insigte in die Westers-Christelike tradisie rakende hedendaagse bevraagtekening van God se teenwoordigheid
}

\author{
J H Vorster (Centurion) ${ }^{*}$ \\ Navorsingsassosiaat: Departement Dogmatiek en Christelike Etiek \\ Universiteit van Pretoria
}

\begin{abstract}
Where is God? Insights in the Western Christian tradition relevant to current questioning of God's presence

Departing from a contemporary question, this article sets out to explore the tradition behind a problem in the modern concept of God. Three historical cross-sections from the tradition, connecting the modern reader with the Old Testament, are presented as summary of the background and development of Christian views of God (focusing on transcendence and immanence as reciprocal concepts). Traditional reflections of this kind utilize a philosophical vocabulary. Accordingly, theology and philosophy exemplify a similar development. $A$ unilinear presentation of insights from the fields of theology and philosophy supports the conviction that all theology is based on some set of what are often are philosophical presuppositions. The aim of this exploration is, firstly, to show that as far as the debate about awareness of God is concerned, the concepts of transcendence and immanence are still highly relevant, and, secondly, to elicit reaction and further debate.
\end{abstract}

\section{INLEIDING}

\subsection{Benadering}

Die Bybel verwoord ' $n$ wye verskeidenheid religieuse ervarings wat op ' $n$ bepaalde historiese punt betekenis gehad het in gelowiges se soeke na 'n

\footnotetext{
"Dr J H Vorster is 'n navorsingsassosiaat van prof dr Johan Buitendag, Departement Dogmatiek en Christelike Etiek, Fakulteit Teologie, Universiteit van Pretoria.
} 
manier om God te verstaan en sin te maak van die lewe. Die opgetekende weergawes verteenwoordig dikwels meer as bloot ' $n$ enkele dimensie, eerder ' $n$ histories gelaagde samestelling van gedagtes en oortuigings - ook rakende die wese van God. Hierdie besondere teologiese konfigurasies kan steeds van groot nut wees in pogings om moontlike antwoorde te bied op moderne vorme van die vraag na God se teenwoordigheid, mits die Bybelse verwoording in hul eie godsdiens-historiese raamwerk verstaan word. Ervaring van God gaan histories verder terug as dit wat in die Ou Testament op skrif gestel is. Wat neergeskryf is, dra gevolglik spore van die filosofiese sowel godsdiens-historiese omgewing en ontwikkeling waarvan die outeur deel was. Behalwe hierdie Bybelse erfenis van multi-dimensionele teologiese konfigurasies, beskik die moderne teologie oor 'n nog omvangryker rykdom aan Godservaring. Die Ou en Nuwe Testamente word reeds vir meer as twee millennia telkens in volgende historiese situasies nuut geïnterpreteer en so van nuwe betekenisse voorsien. Hierdie ketting van herinterpretasie is die band wat die moderne teoloog aan die Bybelse vertellings verbind.

Die vorige eeu kon geen afdoende omvattende teologie van die Ou/Nuwe/beide Testamente oplewer nie. Die uiteenlopende verskeidenheid van godsdienstige bewuswording in die Bybel kan eenvoudig nie deur 'n enkele konsep (of selfs 'n groep konsepte) omvat word nie. Hoewel sommige teoloë byna verbete sal bly vashou aan die droom van 'n Bybelse Teologie wat beide Testamente omvat (Hasel [1972]1979:143) en byvoorbeeld Childs (1992) wat met sy Biblical Theology of the Old and New Testaments steeds daarna streef, blyk die soeke na 'n ander benadering meer en meer nodig (Hasel 1979:129). So pleit Albertz (1992:37) vir 'n herwaardering van die godsdiensgeskiedenis as die meer betekenisvolle en omvattende OuTestamentiese dissipline, waardeur dit moontlik kan word om hedendaagse teologiese vrae sinvol met die Bybel in verband te bring. ${ }^{1}$ Hierdie benadering behels dat moderne vraagstelling as die beginpunt dien om tematiese dwarssnitte uit die godsdienstige geskiedenis van Israel en die Christendom te deursoek vir insigte wat met die oorspronklike vraag verband hou. Die soeke na relevante insigte sluit, behalwe die Israelitiese en die vroegChristelike godsdienste, logies die hele teologiese tradisie tussen die hedendaagse vraag en die Bybel in.

Hierdie artikel ${ }^{2}$ vorm deel van so 'n godsdiens-historiese benadering. Dit behels sowel die probleemstelling as die ondersoek na die tradisie tussen die moderne vraag en die Ou Testament. In artikels wat hierop volg, sal die

\footnotetext{
${ }^{1}$ Vergelyk in hierdie verband ook Barr (1999:118-123, 607).

2 'n Verwerking en uitbreiding van 'n gedeelte van Vorster (1994:2-19) se ongepubliseerde proefskrif.
} 
fokus verskuif na insigte in die godsdiensgeskiedenis van Israel wat relevant kan wees tot die vraag wat hier gestel is.

\subsection{Probleemstelling}

'n Nederlandse priester wat tussen die arm mense van Brasilië werk waar God en kerk toenemend deur dié mense as geslote, afsydig en ontoeganklik ervaar word, verwoord die noodroep van die mense onder wie hy werk in die titel van sy boek - Deus, onde estas? (God, waar is U?...) - en lê sterk klem daarop dat God en kerk aan gelowiges in hulle swaarkry teruggegee behoort te word (Mesters:241-249). ${ }^{3}$ Drie dae ná die dade van terreur op 11 September 2001 in New York, besluit Yancey om 'n spesiale uitgawe van een van sy vorige werke onder die titel Where is God when it hurts? uit te gee. Hy dra dié uitgawe op aan die slagoffers en hulle families, en skenk alle wins daarop aan die Amerikaanse Rooikruis se rampfonds (Yancey [1977] [1990] 2001:1, 5, 8). Danksy hoogs ontwikkelde tegnologie word die hele skrikwekkende gebeurtenis, die weerwraak in Afghanistan, gevolg deur 'n kontroversiële oorlog teen Irak, regoor die wêreld gebeeldsend. Selfs in armoedige Suid Afrikaanse plakkershutte (waar dikwels niks is om te eet nie, maar wel 'n televisiestel aangedryf deur soms onwettige elektrisiteit) kon mense sien hoe vegvliegtuie korrel vat om strategiese teikens na willekeur te tref. Hierdie beelde van fanatisme en politieke waansin skuif skielik op die agtergrond toe die tsoenami van 26 Desember 2004 ryk toeriste en arm boorlinge eenders behandel, en miljoene oorlewendes (wat reeds vooraf armoedig was) in uiterste ellende agterlaat. Nog was dit nie die einde nie. Minder as 'n jaar later op 28 Augustus 2005 ruk die orkaan Katrina die sluiers van 'n swak Amerikaanse ondersteuningsnetwerk af wanneer slagoffers van die ramp mekaar begin beroof terwyl die lyke van bejaardes nog in oorstroomde strate op hulle rolstoele rondsit.

Plaaslike toestande laat groei die reeds bestaande massa onbegryplikhede. Mense in my geboorteland ly onder 'n sindroom van gebrek wat veel wyer as die pandemie van verlies aan immuniteit reik. Rykdom aan die een kant, en hartverskeurende armoede aan die ander, het in 'n "nuwe" Suid Afrika alle historiese grense oorvloei. Miljoene is steeds werkloos en

\footnotetext{
${ }^{3}$ Mesters lewer vanuit ' $n$ eksistensiële vertrekpunt ' $n$ ernstige pleidooi om die waardevolle boodskap oor God in die Bybel te bevry van die afgesonderdheid wat groei uit teologieswetenskaplike verwondering - iets wat na sy mening êrens agter in die kerk in afgesonderde studeerkamers boefen word en teoloë die voorreg van besondere perspektief op God, die Bybel en God se betrokkenheid by die wêreld bied. Hierdie bevoorregte posisie is egter net vir geleerdes deur 'n sydeur toeganklik - terwyl die kerkdeur aan straatkant gesluit bly. Hy droom oor ' $n$ tyd waar teoloë weer tussen die mense wat God nodig het van straatkant af deur die voordeur sou inkom - sodat die in werklik eksistensiële nood weer deur die teoloë tot dankbare verwondering oor God se nabyheid gelei kan word. Vir 'n meer volledige samevatting van Mesters, kyk Vorster (1997:556-561).
} 
honger, en het dikwels te min om selfs hulle eie dooies te kan begrawe. Staatsprogramme ten opsigte van behuising en maatskaplike ondersteuning, sowel as plaaslike regeringsinstansies, word getap deur die lang vingers van korrupsie. Werkskepping bly nie voor teen die aanwas in bevolking en onwettige immigrasie nie. 'n Inkomste, dak oor die kop, basiese dienste en 'n daaglikse bord kos sal dus na alle waarskynlikheid vir nog baie lank die luukse voorreg van 'n nou veelrassige minderheid bly. Misdaad, wat eerder in persentasies as in rou syfers bedink word, raak almal. 'n Oorlaaide polisiemag moet sonder genoeg patrolliemotors probeer funksioneer, en gevolglik neem ernstige misdaad (soos roof, moord en verkragting) noodwendig toe. Verder noord in Afrika lyk dit nie beter nie. Inteendeel, in burgeroorloë en etniese stryd word selfs kinders ingespan as soldate - of baie van hulle sterf gewoon van honger. Diktators heers ongehinderd, en skending van menseregte word nie ernstig geneem nie. Hulpprogramme is óf ontoereikend, óf die moontlike uitwerking daarvan word weens vernietigde infrastruktuur ingeperk (soos onlangs in Zimbabwe waar daar wel noodvoorrade in die land was, maar geen brandstof om dit na afsetpunte te versprei nie). So gesien weerklink Mesters en Yancey se vrae onteenseglik ook uit Afrika. Waar is God, hier waar dit seermaak? Het God, wat naby moes wees, so vér weggestaan dat Hy nie meer wil sien of hoor nie?

'n Nuwe millennium het in Afrika aangebreek, met die transendensie ${ }^{4}$ en immanensie ${ }^{5}$ van God as eeue-oue vraag terug op die tafel van die teologie.

\subsection{Oorsprong van die begrippe transendesie en immanensie}

Volgens H Blumenberg (RGG VI, 989-997) is die oorsprong van die begrip "transendensie" in die filosofie te vinde (Parmenides, Xenophon, Plato, Aristoteles, Basilides, Plotinus, Leibniz, Descartes, Kant, Wittgenstein) en veronderstel die term "... eine heterogene, unbedingte, nicht objektivierbare Wirklichkeit ..." wat bo en behalwe die kosmos bestaan, en nie deur begrippe wat kosmies georiënteerd is omvat kan word nie. Wanneer die term met God

\footnotetext{
4.Die konsep transendensie, afhangende van die konteks waarin daarna verwys word, kan die volgende betekenis dra:

- $\quad$ Die filosofiese siening dat die hoogste beginsel van die heelal anderkant die heelal te vinde is;

- $\quad$ Die siening dat God menslike beperkings te bowe gaan;

- $\quad$ Enigiets wat menslike ervaring (nie soseer menslike kennis nie) te bowe gaan (Deist 1984:175).

${ }^{5}$ Die konsep immanensie kan op die volgende dui:

- $\quad$ Die filosofiese standpunt dat die hoogste beginsel van die heelal en van eksistensie in die heelal te vinde is, en nie in 'n eksterne entiteit soos byvoorbeeld God nie;

- $\quad$ God se teenwoordigheid in die wêreld (Deist 1984:80).
} 
in verband gebring word, beteken dit dat Hy nie onder die gegewenhede van die wêreld te vinde is nie en nie daarmee identies is nie. God gaan nie in geskape gegewenhede op nie, en staan daarmee in 'n verhouding van vrye oorsaaklikheid “... wie ein Erfinder sich zu seiner Maschine, ein Herrscher zu seinen Untertanen, ein Vater ... zu seinen Kindern ...".

Die teenoorstaande term, "immanensie", is logies en histories sekondêr en dui op die gegewe en prinsipieel-ervaarbare bestaan van God in die wêreld. Sedert die tyd van die kerkvaders is hierdie twee terme met die teologie in verband gebring (Augustinus, Anselmus, Thomas Aquinas, Duns Scotus, Bultmann).

Daar bestaan tussen dié terme 'n sisteem van gebalanseerde korrelasie. Menslike bewuswording van God is dus van meet af uitgedruk in terme van 'n paradoks. God is óf ver, óf naby - maar soms tog beide tegelyk. Hierdie kenmerkende "Duplizität" of "Doppelheit in der Offenbarung" (Weber 1977:446 ff), wat ondanks teenstrydige betekenis meestal as begrippepaar in die teologie voorkom, toon ontwikkeling en hou verband met denkrigtings buite die teologie.

\subsection{Die verhouding tussen teologie en filosofie}

Dit word algemeen aanvaar dat, waar dit oor die godsbegrip gaan, die teologie heelwat van die filosofie oorgeneem het. Pannenberg ([1967]1971:296-346) bestee ' $n$ hele hoofstuk aan die opname van die filosofiese godsbegrip as dogmatiese probleem van die vroeg-Christelike teologie; Farley (1962:15) voer met betrekking tot die agtergrond van die teologiese uitdrukking "transendensie van God" aan dat die Hebreeus-Christelike kerugma nooit apart van "... such earthen vessels as Platonism, Aristotelianism, Scolasticism, Kantianism, or existensialism ..." bestaan het nie; Brunner ([1946]1972:155-159) onderskei in 'n appendiks getiteld "Der Gottesgedanke der Philosophen in der Geschichte" behalwe die voor-Christelike filosofiese invloed ook twee latere tydperke (die tydperk van die Kerkvaders en Skolastiek, gevolg deur "die Philosophie der Neuzeit") waar die Christendom deur die filosofie beïnvloed is; en Aulén (1930:78) meen: "Die altkirchliche Theologie wird in weitestem Ausmaß dadurch gekennzeichnet, daß das Gottesbild einen auffallenden Abstraktionsprozeß durchläuft.

Selbstverständlich übt die Philosophie bei diesem Prozeß einen starken Einfluß aus."

Die beoordeling hiervan is uiteenlopend. Aan die een kant is daar sienings van verskillende grade van negatiwiteit, soos dat implementering van die filosofiese godsbegrip die teelaarde vir oorbeklemtoning van die transendensie was (Berkhof 1973:114), of 'n “... konfrontasie tussen die God 
van Israel en die Griekse godsleer ...” (König 1982:4) waarin “... onverwerkte Grieks-filosofiese insigte die Bybelse boodskap vermink het ...” (König 1982:7). Aan die ander kant is daar 'n groter toegeeflikheid waar dit beskou word as die vrug van gemeenskaplike vraagstelling en variasies op dieselfde tema (Pannenberg 1971:299).

Die negatiewe beoordeling het egter in die Bybelse Teologie daartoe gelei dat filosofiese werk as vyand van die teologie opgestel is. James Barr (1999:155) beskryf die tegniek as "loose thinking, with avoidance of precise criteria, and with the piling up of negative associations ...." In plaas van die erkenning dat teoloë behalwe teologiese ook filosofiese voorverondestellings het (Barr 1999:152), is 'n swartlys van terme opgestel (positiwisme, historisme, rasionalisme, idealisme, neo-Katianisme ens) wat dan misbruik word om Bybelse materiaal teen sogenaamd ongepaste filosofiese kategorieë te beskerm. Barr beskryf hierdie tegniek soos volg: "Actual understanding or explanation of philosophical identifications made has not been felt necessary: to give the name is enough." Teenoor "loose thinking" en "name calling" argumenteer Barr met erns en oortuiging om die onvermydelike diep filosofiese afhanklikheid van Bybelse teologieë eerder aanvaar te kry. Sodanige aanvaarding behoort na sy mening uit te loop op "proper philosophical justification" wat onafwendbaar tot drastiese verandering in die konsep "Bybelse Teologie" sal lei (Barr 1999:156).

\subsection{Terminologie in die Christelike tradisie}

In die sistematiese teologie is daar verskeie verwante terme wat gebruik word om iets van God se uitsonderlikheid te probeer weergee. Aan die een kant is daar telkens pogings om God se almag en ontoeganklikheid as Skepper en Heerser van die heelal te verwoord. Aan die ander kant bly God tegelykertyd nie ver en eenkant nie. Hy kom naby aan die mens. Hy openbaar Homself en raak betrokke by sy skepping (waarvan die mens deel is), maar dan sonder om in dié proses van sy goddelikheid en verhewe heerlikheid afstand te doen. Om hierdie tweekantigheid van God wat vir die menslike verstand in 'n hoë mate geheimenisvol bly enigsins hanteerbaar te probeer maak, word die terme vir God se heerlikheid sowel as die terme vir sy nabyheid meestal nie los van mekaar gebruik nie. Daar is 'n hele reeks sulke terme wat elkeen met sy eie geskiedenis en klemtoon gebruik word. Die bekendste is sekerlik die terme Deus absconditus (die verborge God) en Deus revelatus (die geopenbaarde God) wat telkens saam aangewend word.

As alternatiewe vir die term Deus absconditus word die terme Deus absolutus (die God wat los staan van openbaring en die mens), Deus vagus (die onverbonde en vrye God) en Deus nudus (God in sy naakte heiligheid) ook 
gebruik. Dit is alles terme wat die afstand tussen God en mens beklemtoon. God se transendensie (die absolute vryheid en verhewenheid bo tyd, ruimte of menslike ervaring) word ruimskoots verwoord.

Vir die term Deus revelatus is daar egter ook alternatiewe. Dit word meestal weergegee met die woorde kondesensie ${ }^{6}$ (God se vrywillige vernedering vanuit 'n hoë posisie) of immanensie (God se teenwoordigheid in die wêreld).

\subsection{Ordening van inligting}

Ek bied verwysings na immanensie en transendensie in drie breë dwarssnitte uit die Christelike tradisie aan.

- $\quad$ Eerstens vra ek na die invloed van die Griekse filosofie op die teologie van vroeg-Christelike periode teologie tot en met die Reformasie.

- $\quad$ Tweedens stel ek die vraag na die reaksie in die teologie op die filosofie van die sogenaamde Moderne en Kontemporêre periodes.

- Laastens val my fokus op die Postmodernisme en die invloed daarvan op teologiese nadenke.

Waterdigte skeidings tussen die gekose dwarssnitte is onmoontlik. Aspekte van die Griekse filosofie sou byvoorbeeld selfs in die moderne teologie uitgelig kon word. Vroeëre invloede vloei oor na latere periodes. So wil Ward byvoorbeeld iemand soos Altizer nie as volbloed "postmoderne teoloog" erken nie daar hy meen dat Altizer se werk nie suiwer op die poststrukturele weergawes van taal en begeerte berus nie, maar ook spore vertoon van die denke van Hegel en Nietzsche (Ward 1998:xl).

Ontwikkeling en vervloeiing ten spyt, volg waarnemings in hierdie studie steeds naasteby 'n historiese volgorde. Die fokus op aanwending van

\footnotetext{
6. Afgelei van die Latynse woord condescensio (con + descendere) wat "a willing descent from a superior position" beteken (Deist 1984:33); Nederlandse term condescentie; Engelse term: condescension; Afrikaanse betekenis "afdaling, verwerdiging, neerbuiging, minsaamheid, neerbuigendheid" (Kritzinger 1977:926). Daar bestaan geen erkende tegniese term in Afrikaans vir hierdie begrip nie en daar is ook geen enkele Afrikaanse woord wat die betekenis van hierdie term genoegsaam weergee nie. Daarom word veral die Nederlandse term meestal netso oorgeneem (Koekemoer 1994). Na analogie van die Engelse term, stel ek "kondesensie" as tegniese term voor, en gebruik dit ook dan verder in hierdie artikel.
} 
die begrippepaar transendensie-immanensie gee egter deurslag, en daarom bied ek die inligting nie altyd noodwendig kronologies aan nie ${ }^{7}$. Soms het ek groot historiese spronge gemaak, en geen aanspraak op volledige historiese ondersoek $^{8}$ rakende die teologie $^{9}$ of die filosofie is moontlik nie. Die oorsigtelike aard van die ondersoek binne die raamwerk van 'n duidelik onoorsigtelike tradisie, lei verder daartoe dat die vlak van veronderstelling soms ongemaklik hoog is. Die risiko van uitbreiding en korreksie bly gevolglik behalwe realisties, ook 'n opwindende vooruitsig.

\section{BEWUSWORDING VAN TRANSENDENSIE EN IMMANENSIE IN TEOLOGIE EN FILOSOFIE}

\subsection{Die Griekse filosofie}

In die tydgleuf en omgewing waarin die Christelike tradisie ontstaan het, is die tafel as 't ware gedek met gedagtes uit die Griekse denkwêreld. Die blote feit dat die vroegste Christelike geskrifte in Grieks geskryf is, bied reeds genoeg rede om te veronderstel dat die Christelike tradisie uit die staanspoor aspekte van die Griekse denkwyse sou insluit. Die invloede uit die filosofie van die Grieke rakende die godsbegrip het transendensie oorweldigend beklemtoon, selfs wanneer betrokkenheid van 'n Opperwese wel oorweeg word. Waarnemings wat myns insiens ter sake is, het hoofsaaklik uit die volgende oorde gekom:

\footnotetext{
${ }^{7}$ Vergelyk H Berkhof (1973:112-117) vir 'n soortgelyke benadering, waar hy 'n beknopte weergawe gee van hoe hy meen dat die transendensie en immanensie van God in die teologie verwerk is. Aangesien Berkhof poog om ' $n$ inleiding tot die Christelike geloofsleer aan te bied, is sy weergawe nie histories volledig nie. Die keuses van wíe hy as illustrasie gebruik, sowel as die groot historiese spronge in sy uiteensetting (bv tussen die kerkvaders en die skolastiek sowel as tussen Calvyn en Barth), is waarskynlik daaraan te wyte dat hy 'n bepaalde punt wil maak. Hy voer naamlik aan dat die denker oor die godsleer vandag steeds genoodsaak is om self uit te maak waar die pad tussen 'n "bijbelse condescentie" en 'n "wijsgerige transcendentie" gevind kan word. Die punt wat hy wil maak (dat die probleem rondom transendensie en immanensie in die teologie nog oop lê - en waarmee ek saamstem), bepaal die metode wat hy volg. My hele betoog in hierdie artikel maak egter duidelik dat ek skerp verskil van Berkhof se filosofiese besluit oor die Bybel wat hy as deel van sy voorveronderstellings maak (die oortuiging dat immanensie "bijbels" en transendensie "wijsgerig" sou wees). Dit verhoed my egter nie om van 'n soortgelyke metode gebruik te maak nie.

${ }^{8}$ Hoewel geboorte- en sterfdatums ter wille van volledigheid en waar beskikbaar wel genoem word, orden ek die inligting eerder volgens die nie-historiese skema transendensie-balansimmanensie. Die resultaat is dat byvoorbeeld 'n volgorde Aquinas-Augustinus-Fransiskus gebruik word, wat binne my skema sinvol is.

${ }^{9}$ Die onvolledigheid word veral aan die einde van die artikel opvallend waar belangrike teoloë soos Fohrer, Jüngel, Panneberg en Moltmann weggelaat word. Die rede daarvoor is eerstens dat hierdie ondersoek ' $n$ verkenning is, en tweedens dat die omvang van die artikel volledigheid by voorbaat uitsluit. Indien dit geregverdig blyk, kan die studie uitgebrei en aangevul word.
} 


\subsubsection{Die Platonisme}

Hoewel Plato (427-347 vC) nie 'n teologie ontwerp het nie, het hy tog by herhaling religieuse vrae bespreek (vgl PI, Ap 23a 1-7; 29d 1-3; 30a 1-4), sodat daar wel 'n beeld van sy godsleer gevorm kan word (De Vos 1973:119). Die basis van sy hele filosofie is 'n dualisme wat bestaan uit die sintuiglik waarneembare wêreld teenoor die ware werklikheid/wêreld van Idees (PI, Phaed $74 \mathrm{~b}-\mathrm{c}$ ). Die goeie of god $^{10}$ is die hoogste Idee, en is "volstrek transendent". Hierdie godheid was vir Plato meer onpersoonlik as persoonlik, en was ook nie vir gebede of offers van mense toeganklik nie (PI, Polit XI, 509b-d; 517 b1-e3; PI, Phileb 30d; 52e; De Vos 1973:120-121). Ook Plato se mensbeeld het met hierdie dualisme gewerk. Die siel hoort by die wêreld van die Idees en is ewig, terwyl hy die liggaam as stoflik en verganklik beskou het (PI, Phaed 82d 183c 2).

\subsubsection{Die godsbeeld van Aristoteles (384-322 vC)}

Hy sien die godheid as die hoogste syn en eerste beginsel (oorsaak) van alle dinge (Arist, Met I, 983a, 8) wat werklik, absoluut en onveranderlik is. 'n Prominente kenmerk van sy godsbeskouing is dat die godheid op sigself gerig is, en dus niks of niemand nodig het nie (vgl Arist, EthEud VII, 1244b, 8 en $1245 b, 15-19)$. Die godheid is volmaakte, suiwere denke en kan nie op iets onvolmaaks gerig wees nie (Windelband 1958:146). Die naaste wat 'n mens aan die godheid kan kom, is deur sy intellek te oefen (Arist, EthNic X, 1179a, 24-30). Daarom staan die godheid bo die wêreld verhewe as die transendente wat nie verbonde is as skepper of bestuurder nie. Van bemoeienis met die wêreld en mens sowel as van 'n persoonlike verhouding tussen mens en godheid, kan daar geen sprake wees nie (O'Connor 1964:54-55). Verder is die godheid dieselfde as oorsaak of die oerbron van alle beweging (Arist, EthEud VII, 1248a, 26), maar tegelyk ook die opperste en finale doel van die kosmos (Arist, EthEud VII, 1249b, 14-15; asook Stace 1969:285).

\subsubsection{Die Stoïsyne (300 vC-180 nC)}

Zeno van Cyprus, Chrysippus en Seneca was onder andere verteenwoordigers van hierdie stroming. Hulle stelsel het neergekom op 'n

\footnotetext{
${ }^{10}$ Waar die godsbegrip van die ou Griekse filosowe behandel word, word die woord "god" met 'n kleinletter geskryf. Die rede daarvoor is dat "god" of "godheid" vir hulle nie op die "God" van die Ou Testament en Christelike tradisie dui nie. Daar kan wel 'n goeie saak daarvoor uitgemaak word dat die "god/godheid" wat filosowe onderskei en aanvoel, dieselfde "God" is wat bloot vanuit ' $n$ ander verwysingsraamwerk ervaar word. Ek meen egter dat dit nodig is om wel so ' $n$ onderskeiding veral tussen die Grieks-filosofiese en meer Christelik-teologiese nadenke oor 'n opperwese te maak. By latere filosowe, soos byvoorbeeld Kant en Nietzsche, vind ek dit gemakliker om wel 'n hoofletter te gebruik - hoewel dit steeds, lyk my, in die filosofie meer oor 'n konsep as oor 'n persoonlike Wese soos הוָר'? gaan.
} 
panenteïstiese religieuse filosofie ${ }^{11}$ waarin die godheid as onpersoonlike beginsel of Mens universi ("verstand/rede/intellek van die heelal", vgl Sen, QNat I Pref 13) beskou word (vgl ook De Vleeshauer 1964:201). Hierdie lewegewende, kreatiewe en besielende beginsel in die werklikheid word

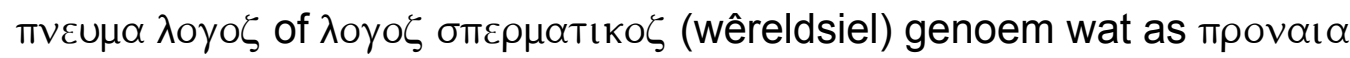
(absolute redelikheid of voorsienigheid) die werklikheid deur middel van

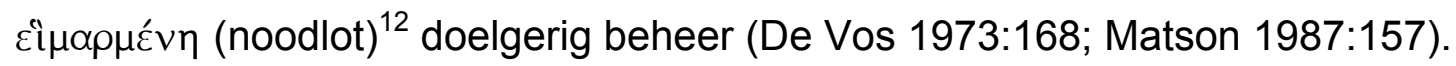
Alles wat bestaan was vir hulle materieel, selfs die siel en die godheid. Die godheid word beskryf as die premordiale vuur wat die oorsprong van die totale werklikheid asook die vonk in die menslike siel is. Omdat alles onder beheer van die absolute redelikheid (voorsienigheid) staan, is daar by hulle ook sterk klem op praktiese etiek waar die mens as ' $n$ rat in die groot masjien moet inskakel by die totale werklikheid (Stace [1920] 1969:344-350).

\subsubsection{Die Neo-Platonisme (200-500 nC)}

Saccas het met hierdie denkrigting begin, hoewel dit eintlik Plotinus was wat dit tot samehangende stelsel met ' $n$ teosentriese karakter ontwikkel het (Feibleman 1959:128-131). In hierdie religieuse filosofie word alles herlei tot die godheid

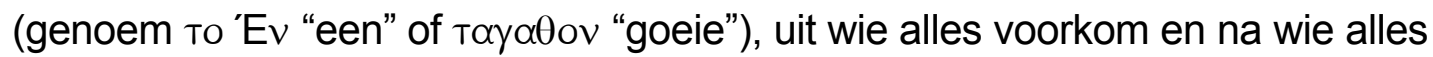
streef (vgl Plot, Enn I 7(54), 1, 21-24 ${ }^{13}$; III, 2(47), 3, 32; V, 1(10)-9(5); asook Boot 1984:367). Plotinus het Plato se dualisme in 'n monisme ingebou waarin alles in oorsprong en doel met die godheid te make het. Die godheid is vir hom die hoogste syn, absoluut transendent en onkenbaar, verhewe bo die veelheid, die syn, die goedheid, die skoonheid. Die godheid werk nie, is selfgenoegsaam, het geen selfbewussyn nie, is onbegrens, oneindig, onverganklik, en sonder ontstaan of gestalte, "de grote $X$.. achter en boven de waarneembare

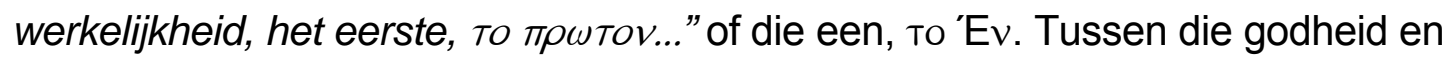

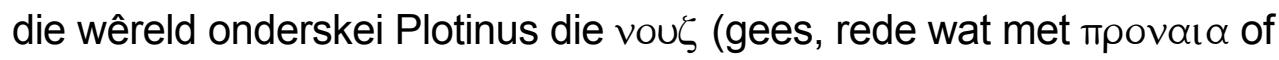
"voorsienigheid" as rasionele plan indirekte beheer uitoefen) en twee vlakke van

\footnotetext{
${ }^{11}$ Vergelyk Sen, QNat, I, Pref 13 en Ross (1974:134): “Quid est deus? Quod vides totum et quod non vides totum. Sic demum magnitudo illi sua reditur, qua nihil maius cogitari potest, si solus est omnia, si opus suum intra et extra tenet." Die godheid, wie se grootheid daarin lê dat hy alles van buite en van binne in stand hou, omvat dus vir Seneca alles (sigbaar en onsigbaar).

${ }^{12}$ Vergelyk Sen, QNat II, 36, 1 waar Seneca sy siening van wat noodlot is, verduidelik: "Quid enim intellegis fatum? Existimo necessitatem rerum omnium actionumque, quam nulla vis rumpat." Dit is 'n noodsaaklike afloop van gebeure en aksies wat deur geen mag verbreek behoort te word nie.

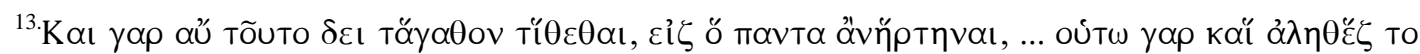

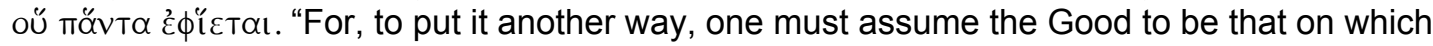
everything else depends, ... for so the statement is true that it is that 'to which everything aspires"' (vertaling van Armstrong).
} 


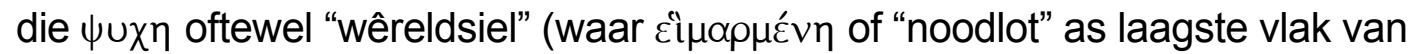
die $\pi \rho \circ \alpha_{\iota} \alpha$ funksioneer). Die wêreld staan dus die verste van die godheid af en is daarom kwaliteitloos en vol kwaad, wat ekstase (losmaking van liggaamlike begeertes) en askese noodsaaklik maak (bg is 'n samevatting van Plot, Enn III, 2(47), 1, 27-28; III, 3(48), 5, 13-20; IV,1(21)-9(8); De Vos 1973:200-205; Matson 1987:175-176; Boot 1984:363-374).

\subsection{Transendensie en immanensie in die Christelike godsbegrip}

Die ooreenkomste tussen die beskouinge van die antieke Griekse filosofie en die Christelike godsbegrip is ooglopend waar dit om die transendensie van God gaan (bv God se ewigheid, onverganklikheid, onbegryplikheid, verhewenheid, heiligheid). Die feit dat die oogmerke van die filosofie en die teologie van mekaar verskil, moet in hierdie verband nie uit die oog verloor word nie ${ }^{14}$. Die ooreenkomste wat egter nogtans bestaan, is verstaanbaar daar teologie nooit in isolasie bedryf word nie, maar elke teoloog in interaksie met sy eie historiese situasie staan en daarom alleen teen die agtergrond van die filosofie van sy tyd verstaan kan word. Boonop is daar ook getuienis van oorvleueling in agtergrond tussen teoloë en filosowe. ${ }^{15}$ Daarom het hierdie filosofiese idees oor 'n verwyderde en verhewe godheid 'n beduidende invloed op die Christelike godsleer bly uitoefen sedert die vroeëre teologie regdeur die Middeleeue en die tyd van die Kerkhervorming. Die invloed het bly geld ten minste tot by die Aufklärung in die agtiende eeu.

\subsubsection{God in die vroeg-Christelike Kerk}

Jesus Christus, die Seun van God, word as mens op aarde gebore. God is so naby as wat Hy aan mense kan wees. Konkrete ervaring van God se teenwoordigheid lê aan die basis van die vroeë getuienis oor Jesus. Van Aarde (1994:142-147) voer byvoorbeeld aan dat die dominante perspektief in Matteus se teologie die Immanuel-tema is, aan die hand waarvan Matteus sy hele vertelling/evangelie inrig met die oog daarop dat sy lesers sal kan insien dat Jesus tot by die wederkoms God-met-ons is. Jesus Christus as God wat mens word, maak die dialektiek tussen God se transendensie en immanensie uit die staanspoor onafwenbaar deel van alle christelik-teologiese refleksie wat sou volg.

\footnotetext{
${ }^{14}$.In 'n gesprek met dr J D Gericke (senior dosent in die Departement Filosofie van die Universiteit van Pretoria) het hy my daarop gewys dat die teologie na sy mening na God soek, terwyl die filosofie op soek is na waarheid.

15. Volgens Matson (1987:193) was Origines en Plotinus klasmaats in die Neo-Platoniese skool van Ammonius Saccas in Alexandrië.
} 


\subsubsection{Vroeëre teologie}

\subsubsection{Die Gnostiek}

'n Voorbeeld van oorbeklemtoning van die transendensie word reeds so vroeg as in die tweede eeu na Christus aangetref. Die Gnostisisme was toe aan die orde. Deist (1984:68) definieer Gnostisisme as 'n godsdienstige en filosofiese stroming onder Jode en spesifiek Christene van 100-600 nC wat geleer het dat die mens slegs deur spesiale kennis van God gered word. Van Aarde (1994:2526) noem die Gnostiek 'n "religieuse ervaring" met 'n pessimistiese wêreldbeeld wat as uitgangspunt het dat die mens en sy wêreld alleen vanuit 'n hoër allesomvattende werklikheid verstaan kan word, en wat met "die onbekende God" as een van hulle "hoofmites" werk. God is vir hulle "the alien God" wat vyandig en absoluut transendent is (Santmire 1985:33).

\subsubsection{Athanasius (297-373) en Origines (185-254)}

Athanasius beskryf sy ervaring van God in terme wat herinner aan Plato en Aristoteles. Hy noem God die "onbegryplike syn" (vgl Athan, Gent 2, 2 waar hy

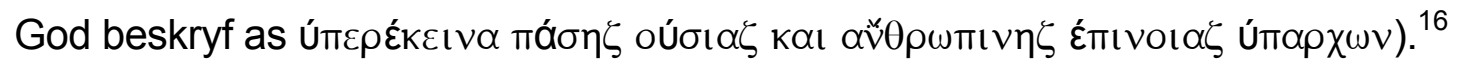
God is onkenbaar, bo substansie en selfs verbeelding verhewe.

Die Godsbeskouing van Origenes vertoon soortgelyk duidelike spore van die filosofie. Hy beskou God byvoorbeeld as die onveranderlike "Een" (Or, Princ I, Preaf, 4: "Primo, quod uno est deus, ..."), wat bo die wêreld verhewe is (sien Or, Princ I, 1, 7 waar hy aanvoer dat God "... eius substantiae ..." is wat nie “... per naturam corporam ..." erken kan word nie aangesien Hy bo “... materia corporali ..." verhewe staan). Origines sluit aan by sy tydgenoot Plotinus met 'n bestaansketting as metafisiese skema waar God as transendente bo aan 'n universele hiërargiese struktuur staan (sien O, Princ I, 5, 1-2 waar hy, met verwysing na, onder andere, Fil 2:10 sê "... elkeen wat in die hemel en op die aarde en onder die aarde is ..." wat uiteindelik voor Christus sal buig, God voorstel as Opperheerser omring deur rasionele geeste). Die aarde is vir Origines die “... terrenae habitationes ..." vir die gevalle geeste (O, Princ I, 5, 5). Santmire (1985:49-50) gee 'n wyer uiteensetting van Origines se standpunte.

\subsubsection{Die reaksie van Irenaeus (140-202)} Irenaeus deur Santmire (1985:31) beskou as "a theologian ... sometimes ... underestimated". Loader (1987:14) beskryf hom as "the first great Catholic

\footnotetext{
16."For God, Maker of all and King of all, that has His Being beyond all substance and human discovery ..." (vertaling deur Robertson 1987:5), of "For God, the Creator and King of the universe who is beyond all being and beyond human imagination ..." (vertaling deur Meijering 1984:16).
} 
theologian". Volgens Santmire kon Irenaeus nóg die Gnostiek se verwerping van die Skeppergod van die Ou Testament, nóg hulle onbewysbare veronderstelling van ' $n$ totaal vyandige en passiewe godheid wat geheel en al van alledaagse ervaring verwyderd staan, ondersteun.

God staan vir Irenaeus op geen manier vyandig teenoor die wêreld nie. God is die oorsaak van alles (Iren, Epid 4, 27). Al is Hy ongeskape, onsigbaar, skepper van alle dinge, bo alle gode verhewe (Iren, Epid 5, 30), Allerhoogste, Almagtige (Iren, Epid 8, 49), koning en regter (Iren, Epid 8, 53) - is dit nogtans Hy wat as Vader (Iren, Epid 6, 39; 8, 49) en genadige, liefdevolle, baie sagte/tere, goeie en regverdige God (Iren, Epid 8, 50) die skepping in stand hou en versorg (Iren, Epid 8, 53). God omvat eerder die hele skepping soos wat 'n ouer omhelsend na 'n kind uitreik (Santmire 1985:35 en 39). Die Gnostiek sien God dus eenkant en vyandig staan, terwyl Irenaeus God eerder as liefdevol en betrokke by die skepping en die mens beskou.

\subsubsection{Die Middeleeue}

\subsubsection{Thomas Aquinas (1224-1274)}

'n Oneindige afstand tussen God en skepping vorm die hoeksteen van Aquinas se denke oor God. God is in goedheid die oorsaak van alles (ThAq, Sum 1, 104, 3: "... bonitas Dei est causa ...") wat as opperheerser (ThAq, Sum 1, 108, 1: “... est Deus princeps non solum omnium angelorum sed etiam hominum et totius creaturae ...") hoofsaaklik indirek regeer (ThAq, Sum 1, 103, 6: “... Deus gubernat quaedam mediantibus allis ..." en 1, 110, 1: “... inferiora in entibus gubernantur per superiora ..."), en só die skepping geheel en al transendeer.

God is vir Aquinas, soos vir Aristoteles, die selfgenoegsame goedheid (ThAq, Sum 1, 103, 6: “... Deus sit ipsa essentia bonitatis ..." en 1, 104, 3: “... divina bonitas non dependet ex rebus creatis ...") wat as abstakte gedagte, soos by Plato, oorvloei na die skepping. Daarom moet alles uiteindelik weer (soos by Plotinus) na God terugvloei (ThAq, Sum 1, 104, 4: “... Finis enim respondet principio ... Ergo ad hunc finem res perducentur, ut nihil sit nisi Deus ...") (vgl ook Santmire 1985:86-94) se bespreking van Aquinas in hierdie verband.

\subsubsection{Augustinus (354-430)}

Augustinus beskou God as "die tydlose, onveranderlike Een" (Aug, Conf VII, ix,14 waar hy God die Vader en die Seun beskryf as "... ante omnia tempora et supra omnia tempora inconmutabiliter ... coaeternus ..." oftewel "... voor alle tye en bo alle tye onveranderlik ... ewig ...") wat ontoeganklik misterieus (Aug, 
Conf I, iv, 4: “... secretissime ... inconprehensibilis ...") is hoewel nie as Deus otiosus (Plotinus se onbeweeglike beweger) nie, maar as altyd aktiewe skeppende (Aug, Conf I, iv, 4: “... innovans omnia ... semper agens ... creans ...") wat alle dinge van naderby verander (sien ook Santmire 1985:60). Die hoogheid, almag, verborgenheid, alomteenwoordigheid, krag en onbegryplike onveranderlikheid van God figureer sterk by Augustinus, maar word gebalanseer met 'n gelyktydige aanvoeling vir God se barmhartigheid. Vergelyk byvoorbeeld Aug, Conf I, iv, 4 waar hy God beskryf as: “... allerhoogste, beste, magtigste, almagtigste, barmhartigste en regverdigste, mees verborgene en tog alomteenwoordige, skoonste en sterkste, standvastige en tog onbegryplike, onveranderlike ...."17 God is vir Augustinus nie slegs onbegryplik en hoogverhewe nie, maar bemoei Hom aktief met die mens. Augustinus is oortuig dat God by hom persoonlik betrokke is. Hy onderskei dié betrokkenheid daarin dat God hom onrustig maak, totdat hy deur innerlike aanskouing van God tot sekerheid kom, en God vir hom dan met "verborge aanraking" van 'n verduisterende geestelike ingesteldheid genees (vgl Aug, Conf VII, vii,12).

\subsubsection{Fransiskus van Assisi (1181-1226)}

Fransiskus beskou God ook as die Allerhoogste en Almagtige, maar sien tegelyk die oorvloeiende goedheid van God in die skepping en skepsels rondom hom raak ( $\mathrm{vgl}$ sy loflied op die skepping oftewel "The canticle of brother Sun" in Habig 1973:130-131). Fransiskus het daarom met die grootste liefde teenoor diere opgetree. By geleentheid het hy volgens sy biograaf, Thomas van Celano, vir 'n swerm voëls langs die pad gepreek (vgl Celano se Vita Prima, 58 in Habig 1973:277-278), en het by 'n ander geleentheid God saam met 'n nagtegaal probeer prys (Habig 1973:1881-2). Hy sien dus 'n noue ontologiese band tussen God en mense aan die een kant en die natuur aan die ander kant, wat 'n Godsverstaan veronderstel waarin die immanensie van God beklemtoon word (Santmire 1985:108-119).

\subsubsection{Reformasie}

\subsubsection{Luther (1483-1546)}

As kind van sy tyd het Luther 'n ervaring van God as Deus absconditus soos duidelik in sy lesing oor Genesis 26:9 (WA 43, 458): “... Esse distinguendum, ... Aut enim disputandum est de Deo abscondito, aut de Deo revelato. De Deo,

17 “... summe, optime, potentissime, omnipotentissime, misericordissime et iustissime, secretissime et praesentissime, pulcherrime et fortissime, stabilis et incomprehensibilis, inmutabilis, ..." 
quatenos non est revelatus, nulla est fides, nulla scientia, et cognito nulla ..." (In LW 5, 44 soos volg vertaal: "... A distinction must be made ... For one must debate either about the hidden God or about the revealed God. With regard to God, insofar he has not been revealed, there is no faith, no knowledge, no understanding ..."[my beklemtoning]). Op daardie stadium nog kon hy nie oor God se transendesie en immanensie in een asem praat nie, aangesien dit vir hom te teenstrydig was. Boonop staan die geregtigheid van God (die oordeel van ' $n$ harde en onbetrokke regter) vir Luther nog in dié stadium voorop. Die noue band wat hy tussen God se geregtigheid en God se straf oor die sonde gehandhaaf het, voed sy oorspronklike beskouing van God as vreesaanjaende Deus absconditus (verhuld, onkenbaar en onverstaanbaar, maar skrikwekkend in sy oordeel).

Hierdie aanvanklike vrees vir God as Deus absolutus/vagus/nudus wat die nabyheid van God in Christus weerspreek, lei later in Luther se lewe daartoe dat hy daarvan probeer ontvlug deur die kondesensie van God oorweldigend te beklemtoon. Uiteindelik kon Luther hierdie vrees met behulp van Paulus se perspektief op God se genade laat bedaar. Dit word duidelik uit Luther se sogenaamde "Toringervaring" (WA, TR 3, 3232c) waarin sy vrees vir die

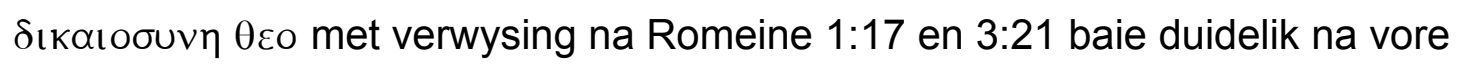
kom. Hy stel dit daar dat die betekenis van die woorde "regverdig" en "regverdigheid van God" sy bewussyn soos 'n weerligstraal tref en hom gevolglik geweldig vreesbevange gemaak het, aangesien God se regverdigheid impliseer dat God ook moet straf. Luther se uitspraak op 12 September 1538 (WA,TR 4, 4007) sluit hierby aan, waar hy sê: Das Wort Gottes Gerechtigkeit ist for Zeiten in meinem Herzen ein Donnerschlag gewest ... von stund an gedachte ich, Gerechtichkeit wäre der grimmige Zorn Gottes, damit er die Sünde strafet. Ich war S. Paulo von herzen feind, wenn ich las: "die Gerechtigkeit Gottes wird durchs Evangelium offenbaret"18. God se oordeel en genade was dus aanvanklik vir Luther radikaal teenstrydig. Ten einde van hierdie vrees vir die "geregtigheid van God" vry te kom, fokus hy dan op die barmhartigheid van God, tot so 'n mate "... dat het soms lijkt of God geheel in zijn condescendentie opgaat ..." (Berkhof 1973:115). Luther het sy vrees vir die oordeel van God as volg verwerk (WA,TR 3, 4007): “... ich lernete und sahe, daß Gottes Gerechtigkeit ist seine Barmherzigkeit, durch welche er uns gerecht achtet und hält. Also ward ich getröstet." (Engelse vertaling in LW 54:309). Hy het eers vertroosting gevind nadat hy God se geregtigheid en barmhartigheid reglynig aan mekaar gelykgestel het. 
Dit kan maklik begryp word waarom byvoorbeeld König (1982:11) 'n waardering vir Luther se beskouing toon: "Hoe merkwaardig anders verklaar Luther byvoorbeeld God se onveranderlikheid. Nie 'n abstrakte kan-nooit-inenige-opsig-verander nie, maar 'n dinamiese getrouheid-om-sy-beloftes-tevervul! By Luther kom dinge weer in sig wat God Gód maak ... hier is die lewende God wat in 'n verbond met sy volk leef, weer ter sprake."

$\mathrm{Al}$ is waardering myns insiens gepas waar dit gaan oor die manier waarop Luther so in geloof en denke die balans tussen die transendensie en immanensie van God herwin, bly dit steeds duidelik hoe kras die invloed van die destydse filosofiese nadenke oor God (waar die oorwig steeds op God se transendensie klem gelê het) hom getref het. Die krag waarmee die filosofie God soos 'n pendulum in die rigting van transendensie geswaai het, kon Luther alleen teëwerk met ' $n$ ewe kragtige terugswaai in die rigting van immanensie. Dit doen hy deur die geregtigheid en barmhartigheid van God in sy denke aan mekaar gelyk te stel. So kragtig was Luther se innerlike weerstand, dat hy later van immanentisme verdink kon word (Berkhof 1973:115). Tog was die uiteinde vir Luther 'n gebalanseerde ervaring van God, 'n gebalanseerde insig wat hom tot in die hede onderskei van die res.

\subsubsection{Calvyn (1509-1564)}

Calvyn het transendensie en immanensie as komplimentêr beskou. Vergelyk in hierdie verband Calv, KatG (in Barth 1963, 1:379-380) waar Calvyn aan die een kant die ontoeganklike majesteit van God as fontein van alle lewe, geregtigheid, goedheid ensovoorts beskryf, maar tog meen dat God iets van sý lewe, wysheid, krag, geregtigheid, genade/goedertierenheid en goedheid in ons laat manifesteer:

Now since the majesty of God in itself goes beyond the capacity of human understanding and cannot be comprehended by it, we must adore its loftiness rather than investigate it, so that we do not remain overwhelmed by so great a splendour ... From God's word, therefore, we learn that our only and eternal God is the spring and fountain of all life, justice, wisdom, virtue, goodness and clemency ... the Lord manifests in us his justice, clemency and goodness. ${ }^{19}$

(vertaling deur Fuhrman 1949:19-20).

19 Or pisque la maieste de Dieu surmonte en soy la capacite de lhumain entendement et mesmes ne peult pas estre comprinse dicelluy, il nous fault adorer sa haltesse plustost que de lenquerir, affin que ne soyons du tout accablez dune si grande clarte ... Nous apprenons doncq de la que nostre Dieu seul et eternel est la source et fontaine de toute vie iustice sapience vertu bonte et clemence: ... le Siegneur declaire en nous sa vie sapience et vertu et exerce envers nous sa iustice clemence et bonte. 


\subsection{Latere filosofie}

Die rasionele kry met verloop van tyd al hoe meer klem. Die menslike rede word die enigste bron van ware kennis wat onafhanklik van die sensoriese waarneming alle menslike ervaring voorafgaan. Sedert die sewentiende eeu ${ }^{20}$ was daar 'n "radikale verandering" in die denke oor God (König 1982:12-13) wat steeds meer vanuit die mens kom met nog minder fokus op goddelike openbaring. Betroubare kennis sou toe slegs moontlik wees op grond van direkte sensoriese waarneming. Dit impliseer dat enigiets wat nie empiries (direk) ervaar kan word nie - nie betroubaar geken kan word nie (König:52). Die uiterste vorm hiervan loop uit op 'n positiwisme waarin slegs sintuiglik waarneembare fenomene/verskynsels (waarvan beskryfbare afleidings deur middel van induksie as verifikasie van metafisiese kennis gemaak kan word) as basis vir kennis kan dien (König 1982:131-132, 81).

\subsubsection{Modernisme}

\subsubsection{René Descartes (1596-1650)}

Die bewys vir die bestaan van God soek Descartes in die rasionele bewussyn van sy eie bestaan en denke (vgl Desc, Med II,4[5]-5). Die idee van God is vir hom 'n objektiewe realiteit wat hy verstaan as oneindig, onafhanklik, alwetend, almagtig en skepper van homself sowel as alles wat bestaan, indien dit wel bestaan. ${ }^{21}$ God is as "allerhoogste goedheid” (vgl Desc, Med I.9[10]: “... Deus... summe bonus ...") die volmaakte of perfekte Wese. Die idee van God dui op volmaaktheid, en volmaaktheid impliseer bestaan aangesien 'n non-eksistente volmaaktheid 'n teenstrydigheid sou wees (vgl Desc, Med I, 9 [11-12] asook Stumpf 1988:243-245).

\subsubsection{Immanuel Kant (1724-1804)}

Die konsep God oftewel "das Wezen aller Wezen" of "Urwezen" is (soos die konsep van die self of "Seele", en die konsep kosmos of "Welt") 'n transendente "Idee", omdat dit met geen objek in ons ervaring korrespondeer nie (vgl Kant 1781:268-271). Hierdie konsepte groei nie uit intuïsie nie, maar uit suiwere rede ("der reinen Vernunft") en vervul as samehangende sinteses van spekulatiewe idees 'n regulatiewe funksie (vgl Kant 1781:435-469) in die sin dat dit 'n rasionele manier verskaf om metafisiese vrae te hanteer. Hoewel hy self rasioneel te werk gaan, slaan Kant die brug na die empirisme deur te stel dat dit

\footnotetext{
${ }^{20}$ König (1982:12-13) sien die radikale verandering eers in die agtiende eeu, hoewel dit myns insiens reeds in die sewentiende eeu begin het.

${ }^{21}$ Vergelyk Desc, Med III, 13 [10-14]: “... rursus illa per quam summum aliquem Deum, aeternum, infinitum, omniscium, omnipotentem, rerumque omnium, quae praeter ipsum sunt, creatorem intelligo, ...”; asook I,10[1-2]: “... aliquem Deum mallant ...”; en I,9[2]: “... Deus esse qui potest omnia, \& a quo talis, qualis existo, sum creatus".
} 
onmoontlik is om kennis van 'n realiteit wat nie ervaar kan word nie, te hê. Hy wys ook daarop dat die Rasionaliste 'n fout begaan deur transendente idees/konsepte as transendente objekte/wesens te hanteer (Stumpf 1988:309310).

\subsubsection{Kontemporêre filosofie ${ }^{22}$}

\subsubsection{Søren Kierkegaard (1813-1855)}

Die term "eksistensie" (bestaan) is in Kierkegaard se denksisteem die vertrekpunt (Poijman 1984:13-21). Om te bestaan, impliseer dat 'n mens 'n indiwidu moet wees wat strewes het, alternatiewe oorweeg, kies, besluit, en toegewyd is (Stumpf 1988:476). Sy onderskeid tussen subjektiewe en objektiewe waarheid speel 'n belangrike rol in sy siening van godsdiens. Geloof was vir hom die essensie van godsdiens (Jones 1975:229; Walker 1976:126127). Geloof is egter subjektief, en daarom bestaan God alleen subjektief ${ }^{23}$. God kan dus nie filosofies of rasioneel beskryf word as 'n absolute en kenbare waarheid nie. Geloof word so 'n eksistensiële keuse om op subjektiewe vlak in 'n persoonlike verhouding tot God te staan, wat die enigste alternatief is wanneer die mens besef dat blote estetiese (emosionele) en etiese eksistensie ontoereikend is (Stumpf 1988:482).

\subsubsection{Friedrich Nietzsche (1844-1900)}

Die Europese kultuur aan die einde van die vorige eeu en die feit dat geloof in die Christelike God drasties afgeneem het, het Nietzsche op die punt gebring om te sê: "God is dood". ${ }^{24}$ Dit was vir hom geen skade nie, aangesien God in

\footnotetext{
${ }^{22}$ Kierkegaard en Nietzsche is so lank reeds dood dat hulle moeilik as "kontemporêr" beskryf kan word. Hiermee word egter na 'n periode in die geskiedenis van die filosofie verwys wat in dié vakgebied so benoem word.

${ }^{23}$ Vergelyk Kierkegaard (1988:45-61) waar hy in hoofstuk 2 van sy "Afsluitend onwetenschaplijk Naschrift, tot De Wijsgerige kruimels" (die oorspronklike "Afsluttende uvidenskabilig efterskrift" van 1846, in Nederlands vertaal deur Gerard Rasch) die onderskeid tussen objektiewe en subjektiewe waarheid verduidelik, en geloof as subjektief definieer. Vergelyk veral die volgende uitspraak (Kierkegaard 1988:56): "Maar de gegeven bepaling van de waarheid is een omschrijving van het geloof. Geloof is juist de tegenspraak tussen de oneindige hartstocht van de innerlijkheid en de objectieve onzekerheid. Kan ik objektief God grijpen, dan geloof ik niet, maar juist omdat ik dat niet kan, moet ik geloven; en wil ik in mij geloof blijven, dan moet ik er steeds opletten dat ik de objektieve onzekerheid vasthoud, dat ik in de objektieve onzekerheid 'op 70.000 vaam diepte' ben, en toch geloof." (kyk ook Poijman 1984:118-126).

${ }^{24}$ Vergelyk Nietzsche (1883:I.Vorrede §2) waar dit duidelik word dat Zarathustra vir die mense 'n geskenk bring in die boodskap dat God dood is: "Zarathustra antwortete: .. .Ich bringe den Menchen ein Geschenk ... Als Zarathustra aber allein war, sprach er also zu seinem Herzen: 'Sollte es denn möglich sein! Dieser alte Heilige hat in seinem Walde noch Nichts davon gehört, dass Gott tot ist!'” (vgl ook Stern 1979:139-170).
} 
elk geval syns insiens 'n bejammerenswaardige menslike skepping was ${ }^{25}$. "'Der Vater' in Gott ist gründlich widerlegt, ebenso 'der Richter', 'der

Belohner'." (Nietzsche 1886:3, §53). As ateïs was hy slegs bekommerd oor die nihilistiese konsekwensies van die "dood" van God, aangesien dit na sy mening tot gelykskakeling van mens en dier sowel as ongekende oorloë sou lei (Camus 1969:63-77; Stumpf 1988:384-386). Hy was egter oortuig dat die oorlewingsdrang, oftewel die magsdrang (wat van nature deel is van die mens) en sy sogenaamde "Übermensch"26 sal kan opmaak vir die verlies aan objektiewe outoriteit en die gevolge van die besef dat die Christelike etiek leeg en lewens-ontkennend is. Alle waardes moes daarom na sy mening van voor af geëvalueer word ${ }^{27}$ ten einde sy ideaal (naamlik die mens in beheer van sy drifte) te kon bereik (Makarushka 1986:110-118; Stumpf 1988:389-394).

\subsection{Dialektiese Teologie}

Eksistensialisme dra die kiem van fundamentele sinloosheid (Deist 1984:58), en moes in die reaksie van die teologie verwerk word. In dié proses het Dialektiese Teologie as beweging die benadering ten opsigte van filosofie in die teologie verander en meer intensief gemaak. Teologie en filosofie is aanvanklik openlik in verband gebring, sonder sweem van spanning met die filosofie (vgl Bultmann 1953:17 waar hy openlik stel dat filosowe onafhanklik dieselfde sê as die Nuwe Testament). Behalwe dat die idee dat daar 'n intrinsiek Bybelse denkwyse sou bestaan wat by begrip daarvan moontlik interpretasie sou kon verbeter, groei daar teenstrydig met die aanvanklike benadering ook 'n onderliggende aanmoediging om die filosofie voorts te ignoreer en as vyand van die teologie te beskou (Barr 1999:147). Later

\footnotetext{
${ }^{25}$ Vergelyk die uitspraak (\#927) van Nietzsche in Baeumler (1965:333): “Die Menschen haben Gott geschaffen, es ist kein Zweifel: sollten wir deshalb nicht an ihn glauben? Er hat den Glauben so nötig zum Leben: seien wir doch barmherzig!"

${ }^{26}$ Nietzsche verwys dikwels na die sogenaamde "Übermensch". Vergelyk byvoorbeeld Nietzsche (1883:I, Vorrede §3) waar hy sê: "Und Zarathustra sprach also zum Volke: Ich lehre euch den Übermenschen ... Der Übermensch ist der Sinn der Erde", en verder waar hy dit met die dood van God in verband bring (1883:IV, Vom höheren Menschen §2): "Nun aber starb dieser Gott! Ihr höheren Menschen, dieser Gott war eure grösste Gefahr ... Nun erst kreisst der Berg der Menschen-Zukunft. Gott starb: nun wollen wir, - dass der Übermensch lebe."

${ }^{27}$ Nietzsche is oortuig dat die Christelike waardesisteem in duie gestort het, en dat daar iets in die plek daarvan moet kom. Vergelyk Nietzsche (1887:III §27): “... die christliche Moralität selbst, ... das ist nunmehr vorbei, ... Alle grossen Dinge gehen durch sich selbst zu Grunde, durch einen Akt der Selbstaufhebung: ... Dergestalt gieng das Christenthum als Dogma zu Grunde, an seiner eignen Moral; dergestalt muss auch das Christenthum als Moral noch zu Grunde gehn, - wir stehen an die Schwelle dieses Ereignisses." Dit lei egter tot die vraag: "welche Sinn hätte unser ganzes Sein, ...". Die antwoord lê vir Nietzsche juis in die oorsaak van die skouspelagtige verval van die Christelike waardesisteem, naamlik: die "Sich-bewusstwerden des Willens zur Wahrheit" (selfvernietigende deel van die Christelike waardes) wat van dié skouspel die "hoffnungsreichste aller Schauspiele" maak.
} 
ontwikkel hierdie groeiende verdagmaking veral onder die navolgers van Barth daartoe dat filosofie as wapen gebruik is om opponente te diskrediteer met die suggesties dat hulle "menslike wysheid" bo die "Woord van God" sou verkies (Barr 1999:151).

\subsubsection{Emil Brunner (1889-1966)}

Brunner fokus op die heiligheid van God. Heiligheid is wat van God die "Ganz Andere" maak, en daarom beskryf hy dit as "Wezenstranszendenz" ([1946] 1972:161). Hy onderskei tussen "Wezenstranszendenz" en "Seinstranszendenz", en verduidelik laasgenoemde as dat God absoluut op geen manier immanent in die wêreld is nie. Wanneer "Seinstranszendenz" voorop gestel word, kom dit syns insiens neer op ekstreme deïsme wat vreemd staan teenoor Bybelse Godsbegrip (Brunner 1972:179). God se heiligheid en heerskappy ("Wezenstranszendenz") vind egter voleinding in liefde. Liefde (wat die kern van beide Ou en Nuwe Testamente uitmaak) is soos heiligheid, wesenskenmerk van God (Brunner 1972:186, 195). Die samehang tussen heiligheid en liefde behels dat God met die mens "in volkommene Gemeinschaft" tree (Brunner 1972:193). Dit gaan uiteindelik dus uitsluitlik oor die verhouding tussen God en mens. In dié verhouding speel God die hoofrol, daar Hy homself in liefde aan die mens wil meedeel. Die heerskappy van die heilige God en die "Selbstmitteilung" van die barmhartige/liefdevolle Here word verenig in die "Glanz der Heiligkeit in der Kreatur, und die völlige Gemeinshaft ..." (Brunner 1972:194). Brunner, wat Søren Kierkegaard (1988:18-19) (hoewel buitestaander tot die teologie) as een van die grootste Christelike denkers van die "moderne" tyd beskou het, verwerk die filosofiese gedagtes oor "eksistensie" en subjektiwiteit deur die transendensie van God in 'n eksistensieel immanente en subjektief bevatlike verhouding in te trek.

\subsubsection{Karl Barth (1886-1968)}

Vanuit die openbaring in Christus voer Barth aan dat transendensie juis in kondesensie, op grond van God se vrye wesenskeuse om lief te hê, verwerkliking vind. Vergelyk hiervoor byvoorbeeld KD II, 1, 6, 30, 394 waar Barth soos volg redeneer: "Gott ist der, der in seinem Sohne Jesus Christus alle seine Kinder, in seinem Kindern alle Menschen, in den Menschen seine ganze Kreatur liebt. Gottes Sein ist sein Lieben. Er ist Alles, was er ist, als der liebende." Jesus Christus is die geopenbaarde liefde van God in wie God se genade en heiligheid mekaar ontmoet. Barth beklemtoon dit in KD II, 1, 6, 30, 413 : "Ist Gottes Liebe das, was uns in Jesus Christus offenbart ist, ist Jesus Christus selbst die offenbare Liebe Gottes, dann ist des Trennens zwischen Gnade und Heiligkeit Gottes ein Ende, dann bleibt uns nur die Erkenntnis und 
Anbetung dessen, der gnädig und heilig ist: gnädig indem er heilig, heilig, indem er gnädig ist."

\subsection{Postmodernisme}

Post-modernisme gee erkenning aan menslike onvermoë om 'n geheelbeeld te vorm van wat agter alles lê. Die mens kan dit wat wêreld, tyd, kennis, mens en taal moontlik maak, nie volledig omvat nie (Ward [1997]1998:xxvi). In 'n kuberwêreld (wat as kultuurmetafoor dien) word tradisionele modernistiese reëls en grense van tyd, ruimte en liggaamlikheid gemaklik oorskry deur middel van 'n internetverbinding wat 'n virtuele omgewing vol vryhede ontsluit en gelyktydige kommunikasie met verskillende gespreksgenote (ongeag van waar hulle op daardie oomblik is) moontlik maak. Alomteenwoordigheid kry 'n totaal nuwe definisie (Buitendag 2003:2). Postmodernisme wil nie 'n filosofiese stroming wees nie, maar eerder 'n bepaalde benadering, denkrigting, toestand of ingesteldheid waarin die totale werklikheid herverstaan (Buitendag 2003:4) en die goddelike gesekulariseer word (Ward [1977] 1998:xvi). Die mens word vasgekeerde deel van 'n wêreld van dinge, terwyl God in onbereikbare transendensie geïsoleer word. Duidelik ' $n$ oorwinning vir die immanentisme (Buitendag 2003:4), hoewel van 'n gans ander aard as die immanentisme waaraan Luther verbind sou kon word. Die tradisionele terme transendensie en immanensie word steeds gebruik, hoewel immanensie met ' $n$ ander soort betekenis gevul word om nie meer na die teenwoordigheid van God in die wêreld verwys nie.

\subsubsection{Georges Bataille (1897-1962)}

Bataille se werk kan gesien word as 'n poging om die "totaliteit van wat is" te konfronteer. Menslike lewe is ervaring van beperkings, en word daarom 'n begeerte na voltooiing. Beperkings frustreer die begeerte om met die totaliteit van bestaan immanent ("being of the same order"; Deist 1984:80) te raak. Hierdie begeerte bly onvervuld, aangesien ' $n$ mens eers selfopofferend moet sterf indien die transendente (oftewel die totaliteit van is/bestaan) omhels wil word (James [1997] 1998:6). Bataille sien in die gebruik om offers te bring 'n voorstelling van 'n poging om hierdie begeerte aan te spreek. Die offeraar berei voor vir die offer deur self geestelik los te raak van eie immanensie (verbondenheid met die wêreld van dinge). Dan onttrek die offeraar die offerdier van dieselfde immanensie (die eenwees met die wêreld van ondergeskiktheid waarvan die offerdier intieme ervaring het, maar waarin dit alleen maar 'n betekenislose ding sou bly). Die een wat offer, roep met die offerdaad die offerdier terug na die intimiteit met die goddelike wêreld (die soewereine wêreld van die gode en mites) om immanent te wees met alles 
wat bestaan (Bataille [1997] 1998:16). Dit bly egter vir Bataille 'n probleem dat die mens tegelyk mens en ding is, en dat die beperkings van dinge nie ontsnap kan word sonder om dier te word nie. Pogings om die mens in die wêreld van intimiteit (i e godsdiens) te herstel, faal meestal, omdat dit wat heilig is nie in die immanente vasgevang kan word nie. Sodra wat heilig is in taal en bewussyn verobjektiveer word, is dit nie verder heilig nie en word dit net nog ' $n$ ding in die wêreld van dinge. Selfs ons idees van God word soortgelyk ' $n$ ding wat ervaring van die heilige kan verhoed en daarom geoffer/gekruisig bekoort te word (James [1997] 1998:12-13). God is vir Bataille die afwesigheid van enige objek. "God is nothing if he is not a transcendance in every direction..." (James [1997] 1998:14).

\subsubsection{Jacques Derrida (1930-2004)}

Onder sterk invloed van die eksistensiële filosofie knoop Derrida aan by die filosofieë van Sartre, Husserl, Freud, Nietzsche en veral Heidegger (Hart 1998:159-160), en het groot invloed op literatuurstudie in aansluiting by De Saussure. Allerweë word hy beskou as die vader van die sogenaande dekonstrusiedenke. Die term "deconstruction" ontleen hy aan Heidegger, en wend dit aan as aanduiding van die taak om outoritêre aansprake op "absolute waarheid" in die Westerse filosofiese tradisie bloot te lê.

Dekonstruksie is geen metode nie, maar eerder 'n ingesteldheid (Buitendag 2003:19) of strategie, wat met dualismes as stapelvoedsel, fokus op die ontbloting/afbou/versteuring van die hierargieë en ordes van ondergeskiktheid waar dit aan die basis van die tradisionele filosofie lê (Reynolds 2002). Magsug is na sy mening die dryfveer agter Westerse agendas wat met hiërargiese begrippepare funksioneer (bv man-vrou, wit-swart, waarheidleuen, goed-sleg) waarin eersgenoemde telkens met versweë veronderstelling as dominant aangebied word (Jordaan 2004:14). Hierdie mening, wanneer toegepas op die begrippepaar transendensie-immanensie sou impliseer dat immanensie binne ' $n$ Westerse agenda in stand gehou is (hoewel met seggingskrag) omdat mense nie sonder sodanige perspektief kan klaarkom nie, terwyl transendensie in 'n meer dominante rol ingespan kon word om mag oor mense te behou. Hierteen het Derrida myns insiens gereageer soos hieronder uiteengesit.

Alles begin vir Derrida by taal. In Westers-filosofiese omgewing bestaan taal binne die dualisme van die gesproke woord (teken van 'n gedagte) en die geskrewe woord (teken van 'n teken). Die geskrewe woord/teks/inskripsie (Engels in aanleuning by die Frans signifier) is vir Derrida nie minderwaardig nie, maar ewe goed die draer van betekenistoeskrywings oor die betekende (verengels as signified). Met ' $n$ meer- 
vlakkigheid van betekenis opponeer hy die voorstelling dat elke woord net een ding beteken. Daar is baie moontlike betekenisse vir elke woord, waarin selfs inkonsekwente menings ingebou kan lê. Op die grense van 'n woord se betekenismoontlikhede (ook verengels as margin) skuil 'n verdere dualisme (tussen dit wat ooreenkom met die bedoeling, en dit wat van die bedoeling verskil/differance). Hierdie differance bly meestal ongesê. Dekonstruksie toon dat betekenis die grense oorvloei (Hart 1998:161) - en gevolglik word soms juis die marginale (wat ongesê gebly het) by die bedoeling ingesluit. Kommunikasie is so gesien die oordrag van 'n massa moontlike betekenisse en "waarheid" die produk van wat met gekose betekenisvlak beoog word. Agter enige "waarheid" lê boonop altyd nog 'n ander "waarheid", en agter die tweede "waarheid" ook 'n derde, vierde (ad infinitum). Die probleem is daarom nie dat daar geen waarheid is nie - daar is te veel waarheid (Buitendag 2003:20). Absolute/enkelvoudige waarheid is derhalwe onmoontlik, en tradisionele waardesisteme (insluitend Bybelse waarhede) raak ernstig ondermyn. Hierby voeg Derrida laastens die insig dat taal temporeel gesproke geen statiese betekenis kan hê nie. Tussen verlede en toekoms is daar konstante beweging, en 'n woord kan op 'n bepaalde punt in die hede slegs verteenwoordig wat dit op daardie oomblik omvat het.

Hoewel kontemporêre dekonstruktiewe teologie en geloof volgens Derrida steeds 'n moontlikheid bly, ${ }^{28}$ vind hy geen hulp in die metafisika agter (denkpatroon van) die teologie nie. Daarin word God niksseggend gemaak as die gans andere wat nóg transendent en heeltemal verwyderd, nóg immanent en naby is (Derrida 1998:167). Daarteenoor beskou Derrida die Christelike God as absoluut transendent (Buitendag 2003:22) - die onkenbare godheid wat bestaan te bowe gaan en nie inpas by die onmiddellikheid en eenvoud van 'n oomblik in die hede nie. God kan nie in die teenwoordige eksistensie geopenbaar of ingepraat word nie, en is inderwaarheid 'n onmoontlikheid wat net in geloof kan bestaan (Hart 1998:163-165). Derrida is oortuig dat enige definisie van of dogma oor God vanuit minstens vier hoeke, soos hierbo uiteengesit, beperk is. Dit word beperk deur taal, marginale betekenis, beperkte waarheidsaanspraak en kortstondigheid. Woorde oor God is hoogstens uitdrukkings in eksistensieel-menslike konstruksies of terme, wat weer van voor af gedekonstrueer moet word. Geloof sou dan wees om op God se teenwoordigheid te vertrou sonder die verwagting om dit ooit in die hede te ervaar, 'n lewe gebou op interpretasie van die logiese spore van dekonstruksie, waar aporia (die dooiepunte/paradoksale in die lewe) ervaar

\footnotetext{
${ }^{28}$ Vgl Hart (1998:162) waar hy verwys na 'n uitspaak van Derrida (in 'n onderhoud met Creech J, Kamuf P en Todd J, "Deconstruction in America: An interview with Jacques Derrida", in Critical Exchange 17 (1985):12) waar Derrida aanvoer: "... a real possibility for faith both at the margins and very close to Scripture, a faith lived in a venturous, dangerous and free way ..." bestaan steeds indien die evangeliese boodskap ontbloot kan word.
} 
word. Al is dit haas onmoontlik, kan die beperkings van eksistensiële afstand alleen getransendeer word deur op die differance te fokus (God se gansandersheid) - en liefs glad nie oor God te praat nie.

\subsection{Grepe uit die teologie van die afgelope vyftig jaar}

Ten spyte van Dialektiese Teologie wat God se transendensie en immanensie wou verenig, word die insigte van die modernisme deur die postmoderne benadering tot op die logiese eindpunte daarvan ontwikkel. Die gevolg is steeds skerper verwoordings van wat transendensie sou beteken, terwyl die term immanensie met 'n nuwe maar meer radikale betekenis gevul word. Die invloed van die postmoderne benadering is meer as blote terminologiese ooreenkoms, soos blyk in enkele uiteenlopende standpunte oor God uit die afgelope vyftig jaar hieronder bespreek. God se transendensie en immanesie word ongeag standpunt toenemend radikaal verwoord.

\subsubsection{Harvey Cox (1929- )}

Daar is dié wat die transendensie van God ten alle koste wil behou as sentrum van die godsleer. Harvey Cox is 'n verteenwoordiger van hierdie benadering. Volgens hom onthul God homself altyd as dié een wat oombliklik totaal anders is as die mens, geheel en al onbekombaar vir dwang of manipulasie van menslike kant. Dit is juis God se uiterste verborgenheid wat Hom aldus onderskei. Verder beskou Cox nie die koms van Christus as teofanie nie. God hou nie in Jesus Christus op om verborge te wees nie, maar tree eerder as die "unavailable other" in ontmoeting met die mens. God "verskyn" nie, maar wys eerder vir die mens dat Hy met behoud van sy verborgenheid in die menslike geskiedenis optree (Cox [1965] 1975:226). So word die wêreld vir Cox die uitsluitlike verantwoordelikheid van die vrye sekulêre mens. Die sekulêre mens kom wel die Deus absconditus teë in gebeure van sosiale verandering asook in sy alledaagse interaksie met ander mense, maar hierdie ontmoeting met God vind eers plaas "... at those hard edges where we are both stopped and challenged to move ahead." Daar ontmoet die transendente God die mens, “... at those aspects of our experience which can never be transmuted into extensions of ourselves. He meets us in the wholly other" (Cox [1965] 1975: 229). Hoewel dit moeilik is om te begryp wat die verskil tussen Cox se tipe transendensie (ontmoeting van die "Gans-andere" oftewel transendente God met die mens) en immanensie is, bly hy tog daarby. Waarskynlik weerhou hy hom, ten spyte van die onmoontlike spanning in sy aansprake, ter wille van sy argument daarvan om enigsins van die term immanensie in hierdie verband gebruik te maak. God bly dus vir hom absoluut transendent, en die mens kom wel vir God op die skerp kant van die lewe teë - dan is God nie skielik iets anders as steeds transendent nie. 


\subsubsection{David Jenkins (1925- )}

Op die middeweg is daar wel teoloë wat sowel die transendensie as die immanensie van God wil behou. Jenkins ${ }^{29}$ is oortuig dat dit noodsaaklik is om dit wat transendent en totaal verskillend van die wêreld is, duidelik te onderskei van dit wat immanent en totaal kontinu met die heelal is, sonder om die eenheid tussen die twee te verbreek (1967:53). Jenkins (1967:104) formuleer sy standpunt baie skerp: "Transcendence without immanence makes nonsense of God, immanence without transcendence makes nonsense of man."

\subsubsection{John Robinson (1919-1983) en Thomas Altizer (1927- )}

Die ander uiterste is te vinde in die veelbesproke standpunt van die sogenaamde "radikale Christene" ${ }^{\text {"30 }}$ of "Christelike ateïsme". ${ }^{31}$ Hulle radikaliteit is daarin geleë dat hulle die kruisdood van Jesus Christus sien as die onherroeplike afsterwe van die God van die Ou Testament. Met die opstanding van Christus as vertrekpunt bepleit hulle 'n verabsoluteerde immanentisme. Hierdie denkrigting staan ook bekend as die "God-is-dood-teologie". Robinson, wat ondanks sy latere meer konserwatiewe aanslag steeds as die vader van hierdie rigting beskou word, glo dat die tradisionele (Ou Testamentiese) godsbeeld God vir miljoene hedendaagse mense veraf op ' $n$ afstand geplaas het. Sy bedoeling daarteenoor verwoord Robinson soos volg: "What I want to do is not to deny God in any sense, but to put him back in the middle of life - where Jesus showed us he belongs." Die Christelike (Nuwe -Testamentiese) God staan na sy oortuiging geensins veraf en verwyderd nie. God is betrokke en deurvleg alles. Deur Jesus Christus is God ín, en behoort God áán die wêreld. Daarom is hy oortuig dat ' $n$ hemelse Wese, wie se blote bestaan deur baie bevraagteken word, nie as vertrekpunt gebruik moet word nie. Sy aanbeveling is: "Let's start from what actually is most real to people in everyday life - and find God there" (Robinson \& Edwards 1963:277). ${ }^{32}$ In en deur Jesus Christus het God deel van die hier en nou geword, en Hy het nooit weer teruggetree nie.

\footnotetext{
${ }^{29}$ David Edward Jenkins (gebore 1925) was professor in Teologie aan die Universiteit van Leeds vanaf 1979, en is die Anglikaanse Biskop van Durham in die Verenigde Koninkryk sedert 1984.

30. Vergelyk Robinson J A T (John Arthur Thomas) \& Edwards D L (David Lawrence) waar Edwards (1963:9) sê:"... I should like to be counted as a Christian radical ..."

${ }^{31}$ Vergelyk T J J (Thomas Jonathan Jackson) Altizer waar hy sy werk beskryf as 'n aanvaarding van die noodsaaklikheid van ' $n$ "contemporary Christian atheism" deur middel van konstruksie van 'n teologiese analise gebou op die christelike insigte van Blake, Hegel en Nietzsche (Altizer 1967:23). Die "radical Christian" glo hy moet beskou word as "... a reformer ... a revolutionary, he is given to a total transformation of Christianity ..." (Altizer 1967:26).

32.Vergelyk ook Altizer (1967:107) wat die dood van God as "good news" oftewel evangelie beskryf en dan vervolg: "... the death of God does not propel man into an empty darkness, it liberates him ... and makes possible his transition into ... the final coming together of God and man."
} 
Later volg Altizer (1967:107) naastenby dieselfde lyn van denke wanneer hy die dood van God as "good news" oftewel evangelie beskryf en dan vervolg: "... the death of God does not propel man into an empty darkness, it liberates him ... and makes possible his transition into ... the final coming together of God and man."

\section{SAMEVATTENDE OPMERKINGS}

\subsection{Dichotomie en ewewig: 'n Herhalende patroon in nadenke oor God}

Uit die manier waarop die terme transendensie en immanensie in die teologie en filosofie aangewend word, blyk 'n aanvoeling vir die dialektiek tussen die uiterstes van die grootheid en die nabyheid van God. God se verhewenheid enersyds, en sy teenwoordigheid andersyds, word meestal gesien as verskillende sektore ${ }^{33}$ van dieselfde geheimenisvolle selfopenbaring van God teenoor die mens. Tog kom oorbeklemtonings van die transendensie (wat uitloop op deïsme) of immanensie (in uiterste vorm genoem panteïsme) gereeld weer voor. 'n Gebalanseerde posisie, waar ewewig en balans in sintese tussen transendensie en immanensie gehandhaaf word, staan uit as hoogtepunte. So 'n middeweg, wat verskillende grade van panenteïsme ${ }^{34}$ vertoon, is in elke dwarssnit opvallend.

\subsection{Kan die moderne vraag na God uit die tradisie beantwoord word?}

Wanneer die uiterstes van transendentalisme (soos by Cox), die middeweg (soos by Jenkins) sowel as immanentisme (soos by Robinson) met mekaar in verband gebring word, blyk God se transendensie die probleem te bly. Al drie denkrigtings (hoewel met uiteenlopende vertrekpunte en resultate) soek maniere om die transendente God in ontmoeting met die mens te $\mathrm{kry}^{35}$.

\footnotetext{
${ }^{33}$ Vergelyk Berkhof (1973:111) wat kies om eerder die meetkundige beeld "sector" te gebruik: "wij hebben in de openbaring niet te doen met een willekeurig afgesneden segment uit de cirkel van God's wezen, maar met een sector, een stuk dat reikt tot in het middelpunt zelf."

34. Panenteïsme waarin aanvaar word dat alles in God en God in alles bestaan (Deist 1984:121) is die "All-in-Gott-Lehre" van K F C Krause (1781-1832), waarin hy gepoog het om die teïsme met die panteïsme te versoen deur 'n panteïstiese wêreldbeskouing met 'n godsbegrip (waarin God sy persoonlike selfbewussyn behou en nie in die wêreld opgaan nie) te verenig RGG V, 36). God is dus in alles, maar steeds groter as die somtotaal van die geheel. Deïsme (verwant aan teïsme) aanvaar 'n bo-wêreldse God wat die wêreld skep en daarna aan sigself oorlaat. Teïsme is "ein relativ moderner geschichtlich gewachsener Terminus" wat ook 'n persoonlike, lewende, bo-wêreldse God aanvaar, maar van die deïsme daarin verskil dat positiewe medewerking van God by sy skepping ingereken word. Teïsme handhaaf dus 'n radikale onderskeid tussen God en wêreld, terwyl dié onderskeid in panteïsme glad nie bestaan nie RGG VI, 733-744).

${ }^{35}$ Vergelyk Sell (1979:61) waar hy (in aansluiting by Schwartzschild, S S in Callahan, D (ed) 1966. The secular city debate. New York: Macmillan.) die mening huldig dat Cox se transendentalisme "turns out to be only verbally different" van die immanentisme waarvan hy juis wou wegbreek.
} 
Dieselfde probleem, naamlik God se absolute transendensie, staan voorop. Dit klop met standpunte in die postmoderne benadering.

In 'n tyd waar die transendensie van God skerper ervaar word as ooit, en 'n dreigende nihilisme (ontkenning van die egtheid van die werklikheid en die betekenis van God weens die verval van objektiewe outoriteit) voor die deur lê, sou pogings om die skaal oor te druk na 'n ervaring van God as uitsluitlik immanent hoogs kunsmatig wees. Pogings om die balans te herstel, het myns insiens 'n veel groter kans om wel 'n impak te maak. In die soeke na ewewig sou dit die moeite loon om te fokus op punte in die tradisie waar een of ander vorm van sintese tussen transendensie en immanensie bereik is. Balans in hierdie noodwendig gekoppelde begrippepaar is duidelik moontlik waar God beskou word as:

- $\quad$ allerhoogste Vader wat die hele skepping omvat (Irenaeus);

- $\quad$ altyd aktiewe maar barmhartige Skeppende wat dinge van naderby verander (Augustinus);

- $\quad$ gelyktydig regverdig/heilig en barmhartig/genadig (die latere Luther en Barth);

- $\quad$ die Fontein van alle lewe wat sy majesteit komplementeer deur iets van sý lewe, wysheid, krag, geregtigheid, genade en goedheid in mense te laat manifesteer (Calvyn);

- $\quad$ die "Wezenstranszendenz" wat die glans van sy heiligheid en liefde aan die mens meedeel en in volkome gemeenskap met die mens laat realiseer (Brunner)

- $\quad$ die Heer wat sy transendensie laat sin maak deur totaal kontinu en immanent met die heelal staan (Jenkins)

Toegespitse aandag aan hierdie fokuspunte in die tradisie dra myns insiens die potensiaal om ondersteuning te bied aan 'n gebalanseerde benadering ("middeweg") waar God in alles te vinde is, maar steeds groter bly as die somtotaal van die geheel. So 'n benadering sal kan standhou, selfs onder moderne en postmoderne bevraagtekening. Teen hierdie agtergrond kan soektogte na relevante ervarings in byvoorbeeld die verskillende lae van die oud-Israelitiese godsdienstige tradisie dermate verfyn word om op bogenoemde fasette te fokus. In ' $n$ toenemend verwarrende werklikheid, selfs waar tradisionele "hoë torings" soos alomteenwoordigheid reeds in postmoderne tydgees paradigmaties geherdefinieer is, moet wat ons ookal 
oor God dink, skryf en praat, die transendente (waaraan niemand meer twyfel nie) opnuut laat inkarneer ${ }^{36}$.

In aansluiting hierby die volgende uitspraak wat Luther in sy uitleg van die "Magnificat" oor God gemaak het (WA VII, 577) en wat Kerr (1966:29) onder die opskrif "Nature of God" groepeer, wil ek aanvoer dat die Christelike tradisie baie waardevolle insigte bevat wat kan inpas in nederige pogings om iets van God te verstaan (en te formuleer) op 'n manier wat weer sin maak vir die mense van ons tyd:

Es haben viel hochvornunftige Menschen und Philosophi auch damit umbgangen, daß sie gern hätten gewüßt, was doch Gott wäre, viel von ihm geschrieben, einer sonst, der ander so; aber sind all droh vorblendet, haben den rechten blick nit ersehen; und ist furwahr das Großiste in Himmel und Erden, daß man Gott recht erkenne, so es lemand werden mag. ${ }^{37}$

(LWD 45, 256)

\section{Literatuurverwysings}

Aland, K 1981. Luther Deutsch, die Werke Martin Luthers in neuer Auswahl für die Gegenwart. Göttingen: Vandenhoeck \& Ruprecht.

Aland, K et al (eds) 1968. The Greek New Testament. New York: United Bible Societies.

Albertz R 1992. Religiongeschichte Israels in alttestamentlicher Zeit. Gottingen: Vandenhoeck \& Ruprecht.

Altizer, T J J 1967. The gospel of Christian atheism. London: Collins.

Armstrong, A H 1978, Plotinus I (Enneads I, 1-9). Loeb Classical Library.

Armstrong, A H 1980. Plotinus III (Enneads III, 1-9). Loeb Classical Library.

Armstrong, A H I 984a. Plotinus IV (Enneads IV, 1-9). Loeb Classical Library.

Armstrong, A H 1984b. Plotinus V(Enneads V, 1-9). Loeb Classical Library, 23

Aulén, G 1930. Das christliche Gottesbild in vergangenheit und Gegenwart.

Gütersloh: Bertelsmann.

Baeumer, A 1965. Friedrich Nietzsche: Die Unschuld des Werdens, der Nachlass. Stuttgart: Kröner. (Sämtliche Werke, vol XI.)

Barnes, J 1984. The complete works of Aristotle, vol 2. New Jersey, NJ: Princeton University Press.

\footnotetext{
${ }^{36} \mathrm{Vgl} \mathrm{Buitendag} \mathrm{(2003:7)} \mathrm{"Die} \mathrm{leer} \mathrm{oor} \mathrm{die} \mathrm{skepping} \mathrm{en} \mathrm{inkarnasie} \mathrm{moet} \mathrm{die} \mathrm{onto-teologieë} \mathrm{en}$ modernistiese humanisme oorstyg."

${ }^{37}$ Teks aangehaal uit LWD 45, 256 en vertaling wat volg soos in LW XXI, 331: "Many philosophers and men of great acumen have also engaged in the endeavor to find out the nature of God; they have written much about him, one in this way, another in that, yet all have gone blind over their task and failed of the proper insight. And, indeed, it is the greatest thing in heaven and on earth, to know God correctly if that may be granted to one."
} 
Barr J 1999. The concept of biblical theology: An Old Testament perspective. Minneapolis, MN: Fortress.

Barth, K 1958. Die Kirchliche Dogmatik. Zollikon: Evangelisher Verlag.

Barth, P (ed) [1926] 1963. Johannis Calvin Opera Selecta, vol 1. Munchen: Kaiser Verlag.

Bataille G [1997] 1998. From theory of religion [1973], tr by Hurley R [1978]), in Ward, G [1997] 1998, The postmodern God: A theological reader. Oxford: Blackwell.

Berkhof, H 1973. Christelijk geloof: Een inleiding tot de geloofsleer. Nijkerk: Callenbach.

Blumenberg, H 1962. s v Transzendenz und Immanenz. RGG VI. 3.Aufl.

Boot, P 1984. Plotinus, over Voorzienigheid. Amsterdam: VU Uitgeverij. (Enneade III 2-3: [47-48].)

Brunner, E [1946] 1972. Die Christliche Lehre von Gott, Dogmatik Band 1. Zürich: Theologischer Verlag.

Buitendag, J 2003. Postmodernisme, Gids TEO 454, Sistematiese Teologie, Universiteit van Pretoria.

Bultmann, R 1953. Kerygma and myth, edited by H W Batsch, London: SPCK.

Camus, A 1969. Nietzsche und der Nihilismus, in Salaquarda, J (ed)1980, Nietzsche. Darmstadt: Wissenshaffliche Buchgesellshaft.

Charlesworth, M J 1970. St Thomas Aquinas, Summa Theologiae, vol 15. London: Eyre \& Spottiswoode. (The World Order.)

Childs, B S 1992. Biblical theology of the Old and New Testament. London: SCM.

Colli, G \& Montinari, M 1968. Nietzsche Werke: Kritische Gesamtausgabe, vol VI, 1. Berlyn: De Gruyter.

Colli, G \& Montinari, M 1968. Nietzsche Werke: Kritische Gesamtausgabe, vol VI, 2. Berlyn: De Gruyter.

Corcoran, T H 1971. Seneca, vol VII. Loeb Classical Library. (Naturales Quaestiones I.)

Cox, H [1965] 1975. The secular city. New York: Macmillan.

De Vleeshauer, H J 1964. Geskiedenis van die wysbegeerte in die weste, vol 1. Kaapstad: Nasionale Handelsdrukkery.

De Vos, H 1973. Inleiding tot de Wijsbegeerte van de Grieken en de Romeinen. Nijkerk: Callenbach.

Deist, F 1984. A concise dictionary of theological terms. Pretoria: Van Schaik.

Derrida J, [1997] 1998. From how to avoid speaking, in Ward, G [1997]1998. The postmodern God: A theological reader, 167-190. Oxford: Blackwell.

Farley, E 1962. The trancendence of God: A study in contemporary philosophical theology. London: Epworth.

Feibleman, J K 1959. Religious platonism: The influence of religion on Plato and the influence of Plato on religion. Connecticut, CT: Greenwood.

Fuhrman, P T 1949. Instruction in faith (1537) by John Calvin. London: Butterworth.

Galling, K et al 1961. Die Religion in Geschichte und Gegenwart. Tübingen: MohrSiebeck.

Gericke, J D 1993. Gesprek met J H Vorster. Pretoria.

Görgemanns, H \& Karpp, H 1976. Origines: Vier Bücher von den Prinzipien. Darmstadt: Wissenschaftliche Buchgeschellshaft. 
Habig, M A (ed) 1973. St Francis of Assisi, writings and early biogaphies: English omnibus of the sources. London: SPCK.

Hamilton, E \& Cairns, H (eds) [1961] 1973. The collected dialogues of Plato.

Princeton, NJ: Princeton University Press.

Hart, K [1997] 1998. Jacques Derrida (b 1930), Introduction, in Ward, G [1997] 1998, The postmodern God: A theological reader, 159-167. Oxford: Blackwell.

Hasel, G [1972] 1979. Old Testament theology: Basic issues in the current debate. Grand Rapids, MI: Eerdmans.

Hefferman, G 1990. René Descates, Meditationes de prima: Philosophia. English \& Latin. Notre Dame: University of Notre Dame Press.

Holsten, W 1962. s v Theismus, RGG VI. 3.Aufl.

Irmischer, J K 1848. Dr Martin Luther's exegetische deutsche Schriften. Erlangen: Karl Hender.

James C [1997] 1998, Georges Bataille (1897-1962) Introduction, in Ward, G [1997] 1998, The postmodern God: A theological reader, 3-15. Oxford: Blackwell.

Jenkins, D E 1967. The glory of man. London:SCM.

Jones, W T [1952]1975. A history of Western philosophy: Kant and the nineteenth century. New York: Harcourt Brace Jovanovich.

Jordaan W, 2004. Derrida draai tradisionele opvattings in tekste, in Beeld 13 Oktober 2004, 14 by http://152.111.1.251/argief/berigte/beeld/.

Kant, I 1781. Kritik der reinen Vernunft, in Hartenstein G, 1867, Immanuel Kant's sämmtliche Werke, 268-271, 435-469. Leipzig: Leopold Voss.

Kerr, H T (ed) 1966. A compend of Luther's theology. Philadephia, PA: Westminster.

Kierkegaard, S 1988. Denken en zijn, 2de druk, Nederlandse vertaling deur Gerard Rasch. Amsterdam: Boom Meppel.

Klein, J 1961. s v Panentheismus. RGG V. 3.Aufl.

Klein, J 1962. s $v$ Theismus. RGG VI. 3. Aufl.

Koekemoer J H 1994. Gesprek met J H Vorster. Pretoria.

König, A 1982. Sistematiese teologie, Gids 2 vir THA200-P, Godsleer. Universiteit van Suid-Afrika.

Kriel, D M 1971. René Descartes se bepeinsinge oor die eerste filosofie waarin die bestaan van God en die onsterflikheid van die siel bewys word. Kaapstad: Academia.

Kritzinger, M S B, Schoonees, P C \& Cronjé, U J (eds) 1977. Groot Woordeboek.

Loader, J A 1987. Image and order, in Vorster, W S (ed), Are we killing God's earth? 24-31. Pretoria: Unisa.

Makarushka, I S M A 1986. Creativity in the thought of Friedrich Nietzsche. PhD dissertation, Boston University.

Matson, W I 1987. A new history of philosophy, ancient \& medieval. Florida, FL: Harcourt Brace Jovanovitsch.

Meijering, E P 1984. Athanasius: Contra Gentes, in Waszink, J H (et al), Philosophia Patrum, vol VII, 16. Leiden: Brill.

Mesters, C [1972] 1995. God, where are you?: Rediscovering the Bible, tr by J Drury \& F McDonagh. Maryknoll, NY: Orbis Books.

Morgan, M L 1992. Plato and Greek religion, in Kraut, R, The Cambridge Companion to Plato, 227-247. Cambridge: Cambridge University.

Nietzsche, F 1883. Also sprach Zarathustra, in Colli \& Montinari 1968: VI, 1. Chemnitz: Ernst Schmeitzner. 
Nietzsche, F 1886. Jenseits von Gut und Böse, in Colli \& Montinari 1968, vol VI, 2. Leipzig: Nauman

Nietzsche, F 1887. Zur Genealogie der Moral: Eine Streitschrift, in Colli \& Montinari, 1968, vol VI, 2. Leipzig: Naumann.

O'Brien, T C 1975. St Thomas Aquinas: Summa Theologiae, vol 14. London: Eyre \& Spottiswoode. (Divine Government.)

O'Connor, D J 1964. A critical history of Western philosophy. New York: The Free Press.

Pannenberg, W [1967] 1971. Grundfragen systematisher theologie. 2.Aufl. Göttingen:Vandenhoeck \& Ruprecht.

Pelikan, J \& Hansen, W A (eds) 1956. Luther's Works. St Louis, MO: Concordia.

Poijman, L J 1984. The logic of subjectivity: Kierkegaard's philosophy of religion. Alabama, AL: University of Alabama Press.

Rahlfs, A (ed) 1935. Septuaginta, 9th ed, vol 1. Stuttgart: Wurtembergische Bibelanstalt.

Reynolds J, 2002. The Internet Encyclopedia of Philosophy: Jacques Derrida, on Deconstructive Strategy by http://www.iep.utm.edu/d/derrida/.

Robinson, J A T \& Edwards, D L 1963. The honest to God debate: Some reactions to the book "Honest to God". London: SCM.

Ross, G M 1974. Seneca's philosophical influence, in Costa, C D N, Seneca. London: Routledge \& Kegan Paul.

Santmire, H P 1985. The travail of nature: The ambigious ecological promise of Christian theology. Philadelphia, PA: Fortress.

Schaff, P (et al) 1987. Nicene and post-Nicene fathers of the Christian church, vol IV. Michigan, MI: Eerdmans.

Sell, A P F 1979. Trancendence, immanence and the supernatural. Journal of Theology for Southern Africa 26, 56-66.

Sizoo, A s a. Augustinus' confessiones: Latijnse tekst met vertaling. Delft: Meinema.

Smith, J P 1952. St Irenaeus: Proof of the apostolic preaching. Ancient Christian Writers, vol 16. Paulist Press: New York.

Stace, W T [1920] 1969. A critical history of Greek philosophy. London: Macmillan.

Stern, J P 1979. A study of Nietzsche. New York: Cambridge University Press.

Stumpf, S E [1966] 1988. Socrates to Satre: A history of philosophy. New York: McGraw-Hill.

Van Aarde, A G 1994. God-with-us: The dominant perspective in Matthew's story, and other essays. Pretoria: Gutenberg Publishers. (HTS Suppl 5.)

Van Aarde, AG 1994. Kultuurhistoriese agtergrond van die Nuwe Testament: Die eerste eeuse Meditireense sosiale konteks. Kital: Pretoria.

Vorster, J H 1994. Aspekte van die verhouding tussen heerskappy en gemeenskap in die kritiese wysheid van Israel. DTh tesis, Universiteit van Suid-Afrika, Pretoria.

Vorster, J H 1997. Resensie van Mesters, C [1972] 1995. God, where are you?, in Rediscovering the Bible, tr by J Drury \& F McDonagh. Maryknoll, NY: Orbis Books. (Old Testament Essays 10/3, 558-561.)

Walker D F 1976. A maker of the modern theological mind, in Duncan, E H, Sören Kierkegaard, 126-127. Waco, TX: Word Books.

Ward, G [1997] 1998. The Postmodern God: A theological reader. Oxford: Blackwell. 
Waar is God? Relevante insigte in die Westers-Christelike tradisie

Weber, O [1962] 1977. Grundlagen der Dogmatiek, Band 1. Neukirchen: NeukirchenVluyn.

White, N P 1992. Plato's metaphisical epistemology, in Kraut, R, The Cambridge Companion to Plato, 277-310. Cambridge: Cambridge University Press.

Windelband, W 1958. A history of philosophy, vol 1. New York: Harper Torchbooks.

Yancey, P [1977] [1990] 2001. Where is God when it hurts? Michigan, MI: Zondervan. 